\title{
Cultural influences on travel lifestyle: a comparison of Korean Australians and Koreans in Korea
}

\begin{abstract}
The purpose of this study was to investigate the difference in the travel behaviour of two groups of Koreans: those resident in Australia and those resident in Korea. A series of items measuring travel specific lifestyle were analysed using factor analysis and cluster analysis. The two groups were classified into four clustered segments based on seven travel lifestyle factors. Chi-square tests were conducted to compare the two groups on the basis of the clusters as well as demographic variables and respondents' travel experiences and preferences. The results included findings that, when comparing the two groups, those Koreans who had migrated to Australia were more likely to avoid group travel, take longer holidays and make travel arrangements without the aid of a travel advisor.

Keywords: lifestyle, travel behaviour, segmentation, Korea, Australia, immigrant, cross-cultural
\end{abstract}




\section{Introduction}

Throughout the world there has been a growing trend of migration to new home countries. However, while research has considered cross-cultural studies of travel behaviour there is a lack of research that specifically investigates immigrants' travel behaviour. That is, most research has tended to focus on nationality as a key investigative variable without due consideration being given to the possibility that a nation may comprise unique sub-cultures of varying ethnic groups, possibly based on recent immigration. Furthermore, questions arise as to how migration to a new host country might influence the tourist through consumer acculturation processes, specifically the attitudes, values or behaviours that the new immigrant might adopt over time to tourism or travel behaviour.

Despite an increase of the Korean immigrant population not only in Australia but also throughout many countries such as the US, Canada and New Zealand, none of the previous studies have focused on this group (Korean immigrants) with reference to their travel-specific lifestyle. According to the annual report of the Department of Immigration and Multicultural and Indigenous Affairs (2005a), the estimated Australian resident population who were born in the Republic of South Korea was 42,679 as at 30 June 2002. Even though the population of Korean immigrants in Australia is small, it continues to increase. The number of Korean permanent additions grew by 2,044 (2001-02), 2,336 (2002-03), and 2,742 (2003-04) across a three year period (Department of Immigration and Multicultural and Indigenous Affairs, 2005b). Presumably, the immigrants' lifestyle is different from other members of the new home nation and may be different from members of their original home country, as an individual's lifestyle is constantly changing according to 
personal, social, economic and political circumstances. Hence, the life of immigrants in a new country with a new culture may present new experiences to them not only in general but also with respect of leisure experiences, including travel. If so, how does the travel-specific lifestyle of immigrants differ from people in their home countries? The answer to this question could provide useful insights for international marketers to extend opportunities in the tourism industry. Thus, the main objective of this study is to explore the similarities and differences in travel behaviour of two distinct groups: Koreans who have migrated to Australia and Koreans who are resident in their home country.

This paper is organised follows: first we review literature including cultural differences in travel, lifestyle segmentation with specific reference to travel, the construct of nationality and how acculturation might influence changes in travel behaviours. Second, we outline the method used to collect self-report data from two

groups of Koreans. Third, we outline the data analysis process used to compare travel behaviours. Finally, the results are discussed including implications for further research.

\section{Literature review}

\section{Cultural influences in travel}

Given the explosion in international travel all over the world, an interest in cultural influences on travel behaviour is growing. Previously, Pizam and Jeong (1996), March (1997), Iverson (1997), Mykletun, Crotts, and Mykletun (2001), and Kozak (2002) have investigated the relationship between tourist behaviour and nationality. However, cross-cultural research has been hampered by the common use 
of nationality as a surrogate for cultural affiliation even though a variety of ethnicities, social classes, lifestyles, and subcultures exist in many countries. This use of nationality occurs even though many countries have been built from large immigrant populations such as in the United States, Canada and Australia (Tan, McCullough, and Teoh, 1987). Although the emergence of ethnic identities has recently been identified as an important factor that impacts upon the attitudes, behaviours of specific cultural groupings and customer segments within countries (Douglas and Craig, 1997), much of the research that has focused on ethnic minorities has also focused on specific populations of the ethnic group such as black American, Hispanic, and Chinese in the United States. Moreover, the study of market segmentation as a way to target or understand the immigrant population (ethnic groups that have moved permanently to another country) has received little attention in the tourism discipline.

Due to historical reasons, Koreans did not have an opportunity for extensive international travel until post 1989 . However, as Korean outbound tourism increased, so too has an interest in this group's tourism behaviour. Mostly, research has sought to define specific travel behaviours of Koreans. One common finding has been the desire or propensity for Korean tourists to travel as part of a group (see for example, Kim and Prideaux, 1998). In related research Pizam and Jeong (1996) argued that that group travel was largely due to cultural rather than to geographic or language factors. However, it is probably due to both culture and language. For instance, Chen (2001) found Korean outbound travellers were concerned about language difficulty problems. Yet, at a more anecdotal level, van Soest (2005) argues that Koreans tend to use packaged tours because it is an easy and quick way to arrange travel. Importantly, this preference for ease and speed is partially culturally derived from the 
work ethic and short vacation times in Korea. Also, Kim (2000) has reported statistics to show an increase in younger generations of Koreans engaging in overseas travel, often accompanied by foreign language training. Based on these data she infers there has been a cultural shift toward leisure pursuits, such as travel.

\section{Lifestyle market segmentation}

Market segmentation is usually the first step in the marketing process and is a process of dividing the total market into relatively homogeneous groups with similar product needs or service interests, based upon such factors as geographic, demographic, socio-economic and psychographic characteristics (Boote, 1981; Gunter and Furnham, 1992; Bécherel, 1999; Swarbrooke and Horner, 1999; Dolnicar, 2004).

Lifestyle has been utilized as one of the most effective segmentation bases within psychographic segmentation. Furthermore, the study of lifestyle has been researched and developed by many researchers in the travel industry. According to an early study (Woodside and Pitts, 1976) regarding the effects of consumer lifestyle, demographics and travel activities on foreign and domestic travel behaviour, lifestyle information may be more important than demographic variables in the prediction of international and domestic travel behaviour. As a result of their study, they advocated that organisations in travel-related industries should make use of lifestyle data as a market segmentation tool. In addition, Schul and Crompton (1983) concluded that travel search behaviour could be better explained by travel-specific psychographic statements. Furthermore, Gladwell (1990) used activities, interests and opinions (AIOs) statements in a study to identify vacation-specific lifestyle and behaviour predispositions of Indiana state park inns' users. It was acknowledged that 
psychographic research including activities, attitudes, interests, opinions, perceptions, needs and daily life routine (or in other words lifestyle characteristics) provides more effective, efficient marketing programs to better understand tourists as consumers.

Chaney (1996) indicated two points to note in relation to the use of lifestyle in the marketing perspective. First, as lifestyle is not a static categorisation, it is continuously changing and must focus on social trends in structural and attitudinal variables. Second, lifestyle analysis needs to focus on the cultural implications of social trends. Particularly as markets have become more internationalised and crosscultural business activity more sophisticated, understanding the culture of the consumer has been recognised as being increasingly important. Cross-cultural research in consumer behaviour has an obvious marketing application to identify groups of consumers with similar behaviours for segmentation purposes (Tan, McCullough, and Teoh, 1987). Thus, lifestyle, and especially that aspect that relates to travel, can be a useful variable for understanding tourism behaviour.

\section{Nationality}

Nationality has been widely employed as a tool of market segmentation in the international tourism market (See for example Kozak, 2002; Lee, Lee and Wicks, 2004; March, 1997; Mykletun, Crotts and Mykletun, 2001; Pizam and Jeong, 1996). For example, Chen (2003) points out that nationality is sometimes used in tourism as an a priori segmentation variable following which other variables of interest (demographic traits and trip characteristics) are then investigated. Other research (Mykletun, et al., 2001) used nationality as a useful predictor for a range of tourism variables including preferences for a destination, perceptions of value and amount of 
money spent at a destination. However, as alluded to in the earlier discussion of culture, the use of nationality as variable might be confounded as a tool for market segmentation for multicultural countries. That is, in multicultural societies many people of differing ethnicities might represent one nationality. So, although someone might hold US nationality it could be that the same person's ethic origin is the more dominant driver of behaviour. Until now, the subculture segment has received little attention from marketers, especially in the tourism industry.

\section{Acculturation}

Linked to the previous section is the role of acculturation. We have argued that studies measuring nationally may be inadequate where there are large migrant populations. In these cases there may be groups who migrate to a country and form sub-cultures based on ethic origin. Nevertheless, it is likely that some level of acculturation takes place that might shape travel or tourist behaviour of migrants.

Acculturation is the process whereby changes in the behaviour patterns of the immigrants may occur as a result of continuous contact with the new host culture (Reilly and Wallendorf, 1984). Acculturation can lead to the incorporation of some elements (such as values and attitudes) of the host community with subsequent changes in behaviour. Importantly, acculturation can occur specifically in terms of consumption behaviour (see for example Ogden, Ogden and Schau, 2004). Similarly, Falk (1995) indicated that ethnically inherent or culturally derived characteristics of a particular community may contribute significantly to patterns of leisure behaviour and, we assume, tourist behaviour. Some immigrants have more access to cultural capital than others depending on individual circumstances, and those influences play an 
important role in the construction of immigrants' lifestyle (Kamo and Zhou, 1994). Juniu (2000) found evidence that some lifestyle changes in a selected group of South American immigrants after migrating to the United States were observed in the participants' socialization patterns, their views about work, and their perception of time. Furthermore, these changes had an impact on their leisure experience and recreation participation. Other research conducted in the United States (Manrai and Manrai, 1995) also confirmed that time usage patterns for work versus social/leisure activities differ across individuals originating from low-context cultures of Western Europe and individuals originating from high-context cultures of Asia, Japan, the Middle East, and South America. Thus, it is assumed that travel-specific lifestyle behaviour of Korean immigrants may be different from Koreans in Korea due to the process of acculturation in a new country.

In summary, we argue that further research is justified to investigate how travel and tourist behaviour differs when a group has migrated to a new host country. In particular, by comparing two groups: one still resident in the home country and one now resident in the new country, we attempt to shed some light onto the topic of the influences of ethic origin versus acculturation from the new country.

\section{Purpose of the study}

The purpose of this study is to identify the presence of differences between Koreans who live in Australia ${ }^{1}$ and those who live in Korea based upon their lifestyles related to travel, on the assumption that the country of residence has an influence on the travel-specific lifestyle of the Korean immigrant in Australia. This research is

\footnotetext{
${ }^{1}$ In this study we use the descriptor Koreans in Australia for those Koreans who have permanent residentship or citizenship in Australia. For the group Koreans in Korea we use the descriptor Koreans only.
} 
guided by the proposition that travel specific lifestyle measures can be used to profile the market into meaningful segments. Based upon this proposition, we raise the following two research questions:

(1) To what extent do the Koreans in Australia differ from, or remain similar to, Koreans in Korea in terms of: representation in the travel specific lifestyle segments; and patterns of travel experiences or preferences?

(2) Do the travel specific lifestyle segments vary in terms of respondent demographics or travel experience and/or preferences for: (a) Koreans in Australia; and (b) Koreans in Korea?

\section{Method}

This study used a self-report questionnaire to obtain information from two groups of respondents: Koreans who had migrated to Australia and Koreans living in Korea. This section describes the development of the questionnaire, the method of data collection and the matching of the samples.

\subsection{Questionnaire}

\section{Measurement of travel specific Lifestyle}

A set of 33 travel-specific lifestyle items selected from the activities/attitudes, interests and opinions (AIO) statements by Perreault, Darden, and Darden (1977), Schul and Crompton (1983), and Silverberg, Backman, and Backman (1996) were used in this study. These statements were designed and applied to elicit information about AIOs specifically related to leisure time/vacation activities and some other general behaviour predispositions. The 33 travel-specific lifestyle items utilised a 7- 
point Likert type scale measuring the degree of agreement/disagreement, from strongly disagree to strongly agree $(1=$ strongly disagree to $7=$ strongly agree $)$.

\section{Other measures}

The respondents were also asked about their travel experiences and preferences including the number of times they had taken international/domestic holidays, the average length of stay, preferred type of travel arrangements, accommodation preferences, and information about travelling companions.

Demographic information included age, gender, income marital status, and level of education.

\section{Adapting the questionnaire to Korean language}

The questions used in this study had been developed and previously applied in the United States, which meant the initial items were designed in English and were potentially ethnocentric to the USA. Thus, two Korean-English bilinguals translated the questionnaire into Korean individually. These two Korean versions were then compared to identify differences in the translation and modified for unification. Back translation into English was carried out by another bilingual person to ensure the accuracy of the translation. Some modifications were made based on a comparison between the original English version of the questionnaire and the back-translated version of questionnaire. In addition, any idiomatic, colloquial English words or phrases in quoted questions from previously established studies were reworded to ensure the translation should be understandable to Koreans in Australia as well as Koreans. Finally, a research instrument administrated in the Korean language was used for this study. A preliminary version of the questionnaire was pilot tested to detect errors or cultural idiosyncrasies. A convenience sample of Koreans in Korea 
and in Australia was used to pre-test the instrument and some minor modifications were made prior to the final data collection.

\subsection{Data collection procedure}

An on-site survey using self-administered questionnaires was adopted as the method of data collection in both countries. Korean's tend to have a low response rate to mail surveys (Chen and Hsu, 2000) so this was discounted as a collection method and the on site survey collection method was chosen. Due to the limitation of access and numbers of Koreans in Australia, convenience sampling was utilised to collect these data. Hofstede (1998) argues that the sample of respondents for comparison studies between countries need not be representative samples from the country's population, but they should be matched as functionally equivalent. Therefore, in this study, we attempted to match both samples from Korea and Australia on a demographic profile basis using age and gender categories that can be visually distinguished.

Koreans in Australia were contacted mostly through various Korean Christian churches and a Buddhist temple on the Gold Coast and Brisbane in Australia from July to August, 2004. Two researchers went to the venues and made an announcement about the survey asking those Koreans who were first generation immigrants to participate in the study. Data collection in Korea was conducted in public places such as shopping centres, residential apartments, offices, and in the street in several cities from September to November, 2004. Once again two researchers approached the respondents and confirmed they were of Korean ethnicity and residency. For the data collection in both locations respondents were given an information sheet outlining the 
study together with a questionnaire. Once the questionnaire was completed the researcher collected the material and placed it in an envelope. A total of six hundred and fifty questionnaires were collected from both countries. However, due to incomplete responses on some questionnaires five hundred and fifty-four questionnaires were accepted for the final sample and used for data analysis.

To investigate any differences on demographic profiles between the samples from Korea and Australia, chi-square tests were undertaken and showed that there were no significant differences on age $\left[\chi^{2}=2.251(\mathrm{df}=3, \mathrm{n}=554), p>0.05\right]$, gender $\left[\chi^{2}=\right.$ $0.067(\mathrm{df}=1, \mathrm{n}=554), p>0.05]$ or marital status $\left[\chi^{2}=6.003(\mathrm{df}=3, \mathrm{n}=553), p>\right.$ 0.05] between the two groups of respondents. However, there was a significant difference for education $\left[\chi^{2}=34.303(\mathrm{df}=2, \mathrm{n}=550), p<0.001\right]$ between the two groups. The reason Koreans in Australia reported holding higher levels of education than Koreans is most likely due to the Australian immigration laws, which allow the highly educated to immigrate with ease. Income data were collected for each sample. However, due to the cross-country collection, the currencies were either Australian dollars or Korean Won. It was not possible to accurately convert these for comparison purposes. However, we classified the respondents into low, moderate or high income based on the respective country data. To do this we took the average weekly earning (for respective countries) and set this in the mid range of our income categories. Based upon the reclassified data, there was no significant difference on income $\left[\chi^{2}=\right.$ $1.356(\mathrm{df}=2, \mathrm{n}=508), p>0.05]$ between the two groups of respondents.

The demographic Characteristics of both Koreans in Australia and Koreans are presented in Table 1. 


\section{Insert Table 1 here.}

\section{Data analysis}

The data collected were analysed using SPSS version 12. First, factor analysis was used to identify a set of underlying dimensions for the travel lifestyle behaviours. Second, the resulting factor scores were then used to identify clusters of respondents with similar patterns of behaviour. Third, Chi-square tests were used to determine if any differences were evident between the Australian Koreans and the Koreans based on the travel lifestyle clusters as well as other travel experiences or preferences. Finally, Chi-square tests were also employed to test for differences in the travel specific lifestyle clusters based on demographic details. This was done for each sample separately.

Using the aggregated data from both samples, the 33 items dealing with travelspecific lifestyle statements were subjected to factor analysis using principal components analysis with orthogonal rotation (varimax) to reduce a large number of variables to a smaller set of underlying factors. Following the deletion of some variables due to cross loadings or poor fit to the factor solution, a total of twenty-five items of the travel-specific lifestyle variables that had a 0.4 or higher loading on only one factor were retained. The final factor solution comprised seven factors with an eigenvalue exceeding 1 , and explained $60.5 \%$ of the total variance. The KaiserMeyer-Olkin Measure of Sampling Adequacy was conducted to ensure the adequateness for factor analysis. The Kaiser-Meyer-Olkin Measure for the data was 
0.800, which suggested these data were suitable for factor analysis as it exceeded the recommended value of 0.6 (Kaiser, 1974; Coakes and Steed, 1999). The Bartlett's Test of Sphericity (Bartlett, 1954) reached statistical significance $(p=0.000)$, supporting the factorability of the correlation matrix. Reliability analysis was performed to test internal consistency of each factor obtained from factor analysis. Each of the seven factors showed a Cronbach alpha of 0.65 or above. Table 2 presents the results of the factor analysis including items, factor loadings, eigenvalues, and Cronbach's alpha.

\section{Insert Table 2 here.}

In order to segment respondents into groups with similar travel-specific lifestyles, a two-step cluster analysis was applied based on travel-specific lifestyle factor scores. The use of factor scores derived from factor analysis is widely used as input for cluster analysis (Singh, 1990). The cluster procedure was undertaken using the aggregated data, as we wanted to identify a common set of clusters across the combined sample that could then be used for comparative purposes in later analyses. In the first step, hierarchical cluster analysis was used to identify the appropriate number of clusters using Ward's method with Squared Euclidean Distance. In the second step, K-mean cluster analysis was conducted to fine-tune the cluster identification process using the hierarchical results as a basis for generating the seed points. The best number of clusters was determined by examining a series of solutions ranging from two clusters to six clusters. All seven factor scores made a significant contribution to differentiating four clusters $(p<0.001)$. Thus, five hundred and fifty- 
four respondents were divided into four segments, which were labelled culturally safe travellers, non-sports activity seeking travellers, independent active travellers, and group travellers. Table 3 shows the final cluster solution based on derived factor scores and the percentage of each cluster.

Culturally safe travellers, which represented 19.7 percent of the sample, characterizes travel enthusiasts who showed the highest cluster scores on 'cultural experience', 'travel interest', but still like to have security in their travel and look to others for advice. However, they had relatively low cluster scores on 'sports interest and information seeking' and 'variety'. By way of a thumbnail sketch, this group tends to be highly interested in travel and likes to have new experiences such as novel foods, different cultures or meeting people rather than organised events like sports or other entertainment. When seeking information, they tend to ask their friends rather than a travel agency.

The next cluster was labelled the non-sports activity seeking travellers, and represented 20.8 percent of the sample. The people in this cluster tended to show the highest cluster score on 'variety' (which includes shopping and festivals), but the lowest cluster scores on 'sports interest and information seeking' and 'indecisive' among the four clusters. In summary, this group tends to like visiting lots of places but doesn't like to do much planning or seeking of advice. They were likely to be uninterested in anything much to do with travel with the exception of variety of entertainment.

The independent active travellers, which represented 34.8 percent of the sample, showed the highest cluster score on 'sports interest and information seeking' in contrast with the clusters of culturally safe travellers and non-sports activity 
seeking travellers. The cluster score on 'group travel' was the only negative score among the seven factor means. The others were all above average. The respondents in this cluster were more likely to be involved in sports activities while travelling, but less likely to travel in groups. This cluster is larger than any of the other clusters, indicating the general travel preferences of the largest group of the sample.

The next cluster was labelled the group travellers, and represented 24.7 percent of the sample. The respondents in this cluster showed the highest positive cluster score on 'group travel' but the lowest cluster scores on 'cultural experience', 'travel interest', 'safe and predictable', and 'variety' among the clusters. This cluster is disinterested in travel and new experiences. However, when they travel they prefer groups. This cluster represents the second largest group among the four clusters.

\section{Insert Table 3 here.}

Next, chi-square analysis was conducted to examine the difference between Koreans in Australia and Koreans in their travel-specific lifestyle based on the four clusters. For the chi-square analysis the magnitude of effect is provided by using either the Phi coefficient for $2 \times 2$ tables, or Cramer's V where there are more than four cells (Field, 2005). In each case the amount of variance explained by the association can be determined by squaring this statistic. In addition, where there were more than four cells, we used the standardised or adjusted standardised residuals to determine which components (cells) of the analysis explained the significant chi-square. As a standardised residual measure is used, if the absolute size of the residual is over two (2), then it was considered that a difference was statistically important. 
The results of the chi-square test found significant differences in travelspecific lifestyle clusters between the two groups $\left[\chi^{2}=14.62(\mathrm{df}=3, \mathrm{n}=554), p<\right.$ 0.01 , Cramer's $\mathrm{V}=.16]$. A profile of the two groups represented in the various clusters is shown in Table 4. An inspection of the adjusted standardised residuals revealed that the main source of variation was from four of the cells: the Koreans in Australia and Koreans in either the non-sports activity seeking travellers or group traveller groups. It was found that a higher proportion of Koreans was in the cluster of group travellers, compared to the Koreans in Australia. This result suggests that the Koreans are more likely to want to travel as part of a group, probably due to language/cultural barriers and minimal travel experience.

It seems that Koreans in Australia were more likely to be represented in the cluster of non-sports activity seeking travellers, than were the Koreans. The Koreans in Australia seem more likely than the Koreans to want to visit lots of places and don't seek advice from others or engage in extensive planning. The Koreans in Australia were more likely to have a preference for activities such as shopping and festivals. The proportion of Koreans was slightly higher than Koreans in Australia for the cluster of culturally safe travellers, suggesting a desire for culturally different experiences but experienced in a safe and secure way. In contrast, more of the Koreans in Australia (rather than Koreans) were represented in the cluster of independent active travellers and were more likely to be independent travellers, have interests in sports activities and like visiting lots of places. The profiling of the differences among the four clusters between Koreans in Australia and Koreans is presented in Table 4. 


\section{Insert Table 4 here.}

\section{Comparison of travel experiences and preferences between Koreans in}

\section{Australia and Koreans}

The results described in the previous section demonstrated that the two groups of Koreans appeared to have different travel-specific lifestyle. Presumably, travel experiences and preferences such as frequency of travel, type of travel arrangements, accommodation and travelling companions may also be different for the two groups. Thus, chi-square analysis was performed to examine whether the two groups differed in their travel experiences and preferences. As illustrated in Table 5, results showed significant differences on the number of times a holiday was taken overseas $\left(\chi^{2}=\right.$ $35.07, \mathrm{df}=2, p<0.001)$, the average length of the holiday overseas $\left(\chi^{2}=82.34, \mathrm{df}=\right.$ $2, p<0.001)$, the arrangement of holiday overseas $\left(\chi^{2}=87.71, \mathrm{df}=1, p<0.001\right)$, the frequency of domestic holidays $\left(\chi^{2}=76.43, \mathrm{df}=2, p<0.001\right)$, the average length of domestic holidays $\left(\chi^{2}=86.71, \mathrm{df}=1, p<0.001\right)$, the preferred type of accommodation $\left(\chi^{2}=47.76, \mathrm{df}=3, p<0.001\right)$, and travelling companions $\left(\chi^{2}=17.96\right.$, $\mathrm{df}=2, p<0.001)$. Only the preferred arrangement for a domestic holiday was not significantly different between the two groups at the 0.05 level.

\section{Insert Table 5 here.}

The responses for Koreans in Australia showed a relatively higher frequency and longer length of international holidays than for Koreans. More than half of the Koreans in Australia preferred to arrange their international holidays by themselves, 
while a large proportion of Koreans preferred to arrange their holidays through a travel agency. In contrast to international holidays, Koreans revealed a trend toward taking more frequent domestic holidays. However, Koreans showed a shorter average length of domestic holidays than Koreans in Australia, probably reflecting cultural differences between Koreans in Australia and Koreans. Koreans in Australia were more likely than Koreans to report staying in hotels when travelling, whereas Koreans were more likely than Koreans in Australia to report staying in apartments. Koreans in Australia were more likely to travel with family members than were Koreans. In contrast, Koreans were more likely than Koreans in Australia to travel with friends. Table 6 presents an overview of the significant differences found between the two groups under study.

\section{Insert Table 6 here.}

\section{Profiles of segmented market for Koreans in Australia}

In order to investigate dominant characteristics of each of the clusters among Koreans in Australia, chi-square tests were conducted using demographics, travel experiences and preferences. For the demographic variables, results revealed that there was only a significant difference across the clusters based on gender $\left(\chi^{2}=14.62\right.$, $\mathrm{df}=3, p<0.01)$. The proportion of females in the culturally safe travellers and nonsports activity seeking travellers clusters was considerably greater than males, while the proportion of each gender in the independent active travellers and group travellers clusters was approximately the same. There were no significant differences on age, marital status, education or income across the clusters. 
In regard to travel experiences and preferences, there were significant differences on the frequency of international holidays $\left(\chi^{2}=8.88, \mathrm{df}=3, p<0.05\right)$, average length of international holidays $\left(\chi^{2}=12.67, \mathrm{df}=3, p<0.01\right)$, and arrangement of holiday overseas $\left(\chi^{2}=12.69, \mathrm{df}=3, p<0.01\right)$ across the clusters. Those Koreans in Australia who are frequent international travellers are more likely than infrequent travellers to be independent active travellers. They also tend to arrange their holidays by themselves rather than through a travel agency. The respondents in the non-sports activity seeking travellers cluster are more likely to have a longer stay while travelling overseas, which is similar to the respondents in the culturally safe travellers cluster. They also have a strong preference for making arrangements by themselves rather than refer to, or use the services of, others. In contrast, the respondents in the group travellers cluster are likely to travel less, and have shorter stays while overseas than any of the other clusters. However, there were no significant differences on the frequency of domestic holidays, average length of domestic holidays, arrangement of domestic holidays, preferred type of accommodation and travelling companions. The results of chi-square tests are displayed in Table 7.

\section{Insert Table 7 here.}

\section{Profiles of segmented market for Koreans}

Next, an investigation of the Korean segment was undertaken to provide depth of insight into demographic influences, travel experiences and preferences. As 
illustrated in Table 8, chi-square tests showed that there were no significant difference for the demographic variables across the clusters among Koreans.

In terms of travel experiences and preferences, there was a significant difference on the frequency of domestic holidays $\left(\chi^{2}=22.96\right.$, $\left.\mathrm{df}=6, p<0.01\right)$ across the clusters among Koreans, and this provides a quite different pattern to the results of Koreans in Australia. The respondents in the group travellers' cluster are likely to travel less than the other clusters, while the respondents in the culturally safe travellers and independent active travellers' clusters are more likely to travel often. The majority of respondents spent one or two days taking their domestic holidays across the clusters even though there was a significant difference on the frequency of domestic holidays. However, no significant differences were found across the clusters on the frequency of international holidays, average length and arrangement of international and domestic holidays, preferred type of accommodation, and travelling companions.

\section{Insert Table 8 here.}

\section{Conclusion and discussion}

In this study we sought to provide insight to the travel similarities and differences of two groups of Koreans: those resident in Korea and those who have migrated to Australia. We theorised that the partial acculturation of the latter group (Koreans in Australia) would lead to different travel preferences and patterns. Our results suggest that the travel-specific lifestyle and behaviours of the sample of Koreans in Australia do differ from the sample of Koreans in several ways. Thus, 
while previous studies have shown differences between nationalities (See Pizam and Jeong, 1996), our study shows that travel differences may occur as a result of migration.

First, in respect of the cluster analysis, which identified four distinct groups, we found that country of residence had a significant impact on representation within each cluster. The cluster of independent active travellers had a similar representation from each group of Koreans. Previously, the Canada/USTTA survey (1993 cited in Karwacki, Deng and Chapdelaine, 1997) identified four distinct target customer segments in the Korean travel market and the results showed "the sports and entertainment" segment, which has similar characteristics to that of the independent active travellers cluster in this study, was an upscale market comprised mainly of males. However, the results of the current study revealed an almost equivalent proportion of gender in the independent active travellers. It might reflect the change of travel lifestyle on gender in changing society. Of particular note were two of the clusters: non-sports activity seeking travellers and group travellers. For the nonsports activity seeking travellers, Koreans in Australia were more likely than Koreans to be represented in this cluster. It seems that these Korean immigrants are more interested in visiting lots of places and do not seek the advice of others when compared to non-immigrants. For the group travellers, the reverse pattern emerged with Koreans more likely to want to travel as part of a group than Koreans in Australia. Thus, within two clusters of travel lifestyle, there appears to be some cultural impact with the Koreans in Australia reporting more independent travel, thus, departing from the normative travel behaviour usually associated with Koreans. For instance, past research (Kim and Prideaux, 1998) has reported that Korean tourists 
enjoy travelling in groups. Similarly, Pizam and Jeong (1996) also found Koreans preferred group travel and they attributed this finding to cultural rather than geographic or language factors. So, while our results support these findings for the Korean sample, we also demonstrated some apparent change in travel lifestyle behaviour for the immigrant group.

There appears to be further evidence that some cultural adaptation has occurred in the group of Koreans in Australia, with responses showing travel behaviour more consistent with the Australian culture. In comparison to Koreans, Koreans in Australia took more frequent and longer holidays possibly reflecting the broader Australian holiday culture. This is consistent with the workplace or industrial conditions of Australia. Furthermore, our results provide some evidence (although not conclusive) that those Koreans now resident in Australia show some signs of assimilating with the Australian way of life when it comes to travel patterns. Further research investigating acculturation level and travel is warranted for migrant populations. Past research (Manrai and Manrai, 1995) has investigated the role of time in cultures and how this impacts on leisure behaviour. Their research found that as immigrants' level of acculturation increased with the host country so too did other behaviours such as time worked and social/leisure hours adopted. While we did not measure time usage our results are consistent with these findings. Future research could look more specifically at perceptions of time and immigrants changes in travel patterns.

The results of the current study also revealed that those Koreans who take a holiday overseas in a group tend to stay less than a week. This can potentially be attributed to two factors: work/leisure opportunities (amount of holidays per annum) 
and/or the accepted way of arranging travel (through a travel agent). In the case of the latter factor, the majority of packaged tours available in Korea, based on advertisements in newspapers and magazines are generally designed for an overseas stay of less than a week. Also, tourists are usually not allowed to change the itinerary or accommodation type. This finding supports Kim and Prideaux's (1998) research where they also identified itinerary construction as an inconvenience to Korean tourists to Australia. By comparison, Koreans in Australia demonstrated more independence, arranging their own travel.

Chen and Hsu (2000) argued that a language barrier frequently makes Korean tourists feel uncomfortable, particularly with merchants. Similarly, Kim and Prideaux (1998) found language difficulty as the greatest inconvenience factor among Korean group tourists visiting Australia (especially Korean tourists aged 51 years and over or housewives). In a similar manner, it is suggested by the results of the present study, that a language barrier may contribute to the preference of group travel for Koreans. It is also possible that the Australian Koreans travel back to Korea when going overseas and thus, have little need of a travel agent to arrange an itinerary. Future research could extend the present study to look at immigration patterns of overseas travel in terms of destinations, specifically if there is a difference in travel behaviour depending on returning to the home country versus other destinations. Furthermore, while the most preferred travel companion was family for the both groups, Koreans in Australia had a higher proportion of respondents indicating family as a travelling companion than did Koreans. This may reflect that the immigrants have a smaller network of friends and rely more on family for travel companions. 
In regard to the travel lifestyle clusters, a further comparison with demographic and travel behaviours revealed that the two groups were somewhat different. Based on travel-specific lifestyle clusters, Koreans in Australia showed differences in travel experiences (behaviour) for aspects of overseas travel, while Koreans showed only a difference in the frequency of domestic travel.

In summary, the two groups have a different nationality, and seem to be influenced by different cultural experiences. Overall, our results indicated that the patterns of travel experiences tended to vary depending on the residential country (that is, between rather than within country). Furthermore, inspection of Cramer's V squared provided evidence that more of the variance in responses was explained by the association of country of residence and travel behaviours. That is, a comparison of Koreans in Australia against Koreans demonstrates more variation than simply looking within a culture. It seems that Koreans in Australia may have more opportunities to enjoy sports and longer domestic holidays due to the socio-cultural environment as well as frequent school holidays, and possibly a high national income. They may need differentiated services and products from those suited to Koreans. In comparison, as the five-day workweek system was partially started from 2003 in Korea, the travel-specific lifestyle of Koreans is likely to demonstrate a gradual change. According to the Korea Times (Park, 2004), more people are visiting neighbouring countries like China, Japan and Southeast Asia for golf trips or sightseeing tours on weekends. Kim (2000) also pointed out that a central feature of contemporary consumerism in Korea is the expansion of leisure activities such as tourism, shopping, eating out and sports. Thus, marketers need to meet the demands of customers in the changing society. Although the population of Korean immigrants 
is small, it continues to increase every year so is worthy of investigation. Furthermore, other ethnic groups also migrate to Australia and it is likely that adaptation and acculturation of travel behaviours will occur. Organisations in the tourism industry are wise to understand that cross-cultural insights provide more opportunities to marketers to develop and extend markets in multicultural countries. Knowledge of consumers' diverse cultural backgrounds can enhance the opportunity to meet customers' expectations, which will in turn result in promotion of the market. In terms of marketing initiatives, this research provides some points for further consideration by marketing personnel. If targeting the Korean immigrant population marketers might focus on offering options for overseas travel aimed more at independent travellers. In contrast, for the Koreans in Korea, a focus on offering outbound group tours seems to be a continued preference. Furthermore, for this group there remains an emphasis on short break holidays closer to home.

\section{Limitations and research suggestions}

One of the most common limitations of comparative studies is applicable to this study, which is that the samples of this study may not be representative of the broader populations of Koreans in Australia or Koreans. Particularly, Koreans in Australia were limited in numbers as well as accessibility. In addition, the current study was limited to the two groups of Koreans, but research aimed at identifying whether Korean immigrants have a different lifestyle from Australians (of several generations) is also needed. That is, perhaps Koreans in Australia have a different lifestyle from other Australians unless they are completely assimilated into Australian society. Future research could consider more multi-method approaches, including 
surveys and individual interviews or focus groups, which may assist in better understanding various ethnic groups. Furthermore, examination of lifestyle determinants such as the level of acculturation and value systems is suggested to clarify the characteristics of the segmented market for marketing implications as well as academic perspectives. 


\section{References}

Bartlett, M.S. (1954). A note on the multiplying factors for various $\chi^{2}$ approximations. Journal of the Royal Statistical Society, 16 (Series B), 296-298.

Bécherel, L. (1999). Strategic Analysis and Strategy Formulation. In F. Vellas, \& L. Bécherel, (Eds.), The International Marketing of Travel and Tourism: a strategic approach (pp. 37-106). London: Macmillan Press Ltd.

Boote, A.S. (1981). Market segmentation by personal value and salient product attributes...demographics tell only part of the story. Journal of Advertising Research, 21(1), 29-35.

Chaney, D. (1996). Lifestyles. London: Routledge.

Chen, J.S. (2003). Market segmentation by tourists' sentiments. Annals of Tourism Research, 30(1), 178-193.

Chen, J.S., and Hsu, C.H.C. (2000). Measurement of Korean tourists' perceived images of overseas destinations. Journal of Travel Research, 38(4), 411-416.

Coakes, S.J., and Steed, L.G. (1999). SPSS: Analysis without anguish. Brisbane: Jacaranda Wiley.

Department of Immigration and Multicultural and Indigenous Affairs. (2005a). Population Flows: Immigration Aspects 2003-04 Edition. Retrieved June 10, 2005 , from http://www.immi.gov.au/statistics/publications/popflows2003_4/pf_append.pdf

Department of Immigration and Multicultural and Indigenous Affairs. (2005b). Immigration Update June 2004. Retrieved June 10, 2005, from http://www.immi.gov.au/statistics/publications/immigration_update/Update_Jun e04.pdf 
Dolnicar, S. (2004). Beyond "commonsense segmentation": A systematics of segmentation approaches in tourism. Journal of Travel Research, 42(3), 244250.

Douglas, S.P., and Craig, C.S. (1997). The changing dynamic of consumer behavior: implications for cross-cultural research. International Journal of Research in Marketing, 14(4), 379-395.

Falk, J.H. (1995). Factors influencing African American leisure time utilization of museums. Journal of Leisure Research, 27(1), 41-60.

Field, A. (2005). Discovering Statistics Using SPSS. $2^{\text {nd }}$ ed. London: Sage.

Gladwell, N.J. (1990). A psychographic and sociodemographic analysis of state park inn users. Journal of Travel Research, 28(4), 15-20.

Gunter, B., and Furnham, A. (1992). Consumer Profiles: An Introduction to Psychographics. London: Routledge.

Hofstede, G. (1998). A Case for Comparing Apples with Oranges: International Differences in Values. In M. Sasaki (Ed.), Values and Attitudes across Nations and Time (pp. 16-31). Leiden: Brill.

Iverson, T.J. (1997). Decision timing: a comparison of Korean and Japanese travellers. International Journal of Hospitality Management, 16(2), 209-219

Juniu, S. (2000). The impact of immigration: Leisure experience in the lives of South American immigrants. Journal of Leisure Research, 32(3), 358-381.

Kaiser, H. (1974). An index of factorial simplicity. Psychometrika, 39(1), 31-36.

Kamo, Y., and Zhou, M. (1994). Living arrangements of elderly Chinese and Japanese in the United States. Journal of Marriage and the Family, 56(August), 544-558. 
Karwacki, J., Deng, S., and Chapdelaine, C. (1997). The tourism markets of the four dragons - a Canadian perspective. Tourism Management, 18(6), 373-383.

Kim, S.K. (2000). Changing Lifestyle and Consumption Patterns of the South Korean Middle Class and New Generations. In B. H. Chua. (Ed.), Consumption in Asia: Lifestyles and Identities (pp. 61-81). London: Routledge.

Kim, S.M., and Prideaux, B. (1998). Korean inbound tourism to Australia - a study of supply-side deficiencies. Journal of Vacation Marketing, 5(1), 66-81.

Kozak, M. (2002). Comparative analysis of tourist motivations by nationality and destinations. Tourism Management, 23(3), 221-232.

Lee, C.-K., Lee, Y-K., and Wicks, B.E. (2004). Segmentation of festival motivation by nationality and satisfaction. Tourism Management, 25(1), 61-70.

Manrai, L.A., and Manrai, A.K. (1995). Effects of cultural-context, gender, and acculturation on perceptions of work versus social/leisure time usage. Journal of Business Research, 32(2), 115-128.

March, R. (1997). Diversity in Asian outbound travel industries: a comparison between Indonesia, Thailand, Taiwan, South Korea and Japan. International Journal of Hospitality Management, 16(2), 231-238.

Mykletun, R.J., Crotts, J.C., and Mykletun, A. (2001). Positioning an island destination in the peripheral area of the Baltics: A flexible approach to market segmentation. Tourism Management, 22(5), 493-500.

Ogden, D.T., Ogden, J.R., and Schau, H.J. (2004). Exploring the impact of culture and acculturation on consumer purchase decisions: Towards a microcultural perspective. Academy of Marketing Science Review, 2004, 1-22. 
Park, C-A (2004). Overseas Travelers Hit Record High. The Korea Times. Retrieved 23. June 2005 from http://times.hankooki.com

Reilly, M.D., and Wallendorf, M. (1984). A Longitudinal study of Mexican-American assimilation. Advances in Consumer Research, 11, 735-740.

Perreault, W.D., Darden, D.K., and Darden, W.R. (1977). A psychographic classification of vacation life styles. Journal of Leisure Research, 9(1), 208-223.

Pizam, A., and Jeong, G-H. (1996). Cross-cultural tourist behavior. Tourism Management, 17(4), 277-286.

Schul, P., and Crompton, J.L. (1983). Search behavior of international vacationer: travel-specific lifestyle and sociodemographic variables. Journal of Travel Research, 22(2), 25-30.

Silverberg, K.E., Backman, S.J., and Backman, K.F. (1996). A preliminary investigation into the psychographics of nature-based travelers to the Southeastern United States. Journal of Travel Research, 35(2), 19-28.

Singh, J. (1990). A typology of consumer dissatisfaction response styles. Journal of Retailing, 66(1), 57-99.

Swarbrooke, J., and Horner, S. (1999). Consumer behaviour in tourism. Oxford: Butterworth-Heinemann.

Tan, C.T., McCullough, J., and Teoh, J. (1987). An individual analysis approach to cross cultural research. Advances in Consumer Research, 14, 394-397.

Van Soest, T. (2005). Traveling Trends. Korean Times (02-17-2005). Retrieved 01. March 2006 from http://times.hankooki.com 
Woodside, A.G., and Pitts, R.E. (1976). Effects of consumer life styles, demographics, and travel activities on foreign and domestic travel behavior. Journal of Travel Research, 14, 13-15. 
Table 1

Demographic characteristics of Koreans in Australia and Koreans

\begin{tabular}{lcc}
\hline $\begin{array}{l}\text { Demographic characteristics } \\
\text { and category }\end{array}$ & $\begin{array}{c}\text { Koreans in Australia (\%) } \\
(\mathrm{n}=272)\end{array}$ & $\begin{array}{c}\text { Koreans }(\%) \\
(\mathrm{n}=282)\end{array}$ \\
\hline Gender & 40.4 & 39.0 \\
Male & 59.6 & 61.0 \\
Female & & \\
Age & 21.3 & 21.6 \\
20-29 years & 33.1 & 33.0 \\
30-39 years & 34.2 & 30.1 \\
40-49 years & 11.4 & 15.3 \\
50 years and over & & \\
& & 27.4 \\
Marital status & 19.9 & 70.1 \\
Never married & 78.3 & 0.7 \\
Married/De facto & 1.1 & 1.8 \\
Widow/Widower & 0.7 & \\
Divorced/Separated & & 9.6 \\
& & 49.8 \\
Education & 14.5 & 40.6 \\
Postgraduate (Masters or PhD) & 67.7 & \\
Bachelor Degree & 17.8 & 34.9 \\
Senior High School or less & & 15.6 \\
Income & 53.6 & \\
Low & 30.1 & \\
Medium & 16.3 & \\
High & & \\
\hline
\end{tabular}


Table 2

Factor analysis of travel-specific lifestyle

\begin{tabular}{|c|c|c|c|c|}
\hline Factors and items & $\begin{array}{l}\text { Factor } \\
\text { loading }\end{array}$ & Eigenvalue & $\begin{array}{c}\text { Explained } \\
\text { variance }(\%)\end{array}$ & $\begin{array}{c}\text { Cronbach's } \\
\text { alpha }\end{array}$ \\
\hline Factor 1: Cultural experience & & 5.21 & 20.83 & 0.78 \\
\hline The local foods and drinks & 0.802 & & & \\
\hline $\begin{array}{l}\text { A new place with new cultures and new ways } \\
\text { of living }\end{array}$ & 0.785 & & & \\
\hline The local people and customs & 0.760 & & & \\
\hline Educational places & 0.599 & & & \\
\hline Factor 2: Travel interest & & 2.54 & 10.16 & 0.80 \\
\hline Taking a trip rather than stay at home & 0.829 & & & \\
\hline $\begin{array}{l}\text { Spending a windfall of money on holiday } \\
\text { travel more than something else }\end{array}$ & 0.792 & & & \\
\hline Interest in travelling & 0.739 & & & \\
\hline $\begin{array}{l}\text { Factor 3: Sports interest } \\
\text { and information seeking }\end{array}$ & & 1.87 & 7.49 & 0.74 \\
\hline $\begin{array}{l}\text { Participating in favourite sports when on } \\
\text { holiday }\end{array}$ & 0.856 & & & \\
\hline $\begin{array}{l}\text { Watching favourite sporting events when on } \\
\text { holiday }\end{array}$ & 0.846 & & & \\
\hline Contact a travel agency for information & 0.580 & & & \\
\hline Looking at holiday or travel magazines & 0.526 & & & \\
\hline Factor 4:Safe and predictability & & 1.71 & 6.85 & 0.68 \\
\hline $\begin{array}{l}\text { Considering the safety of holiday } \\
\text { destinations }\end{array}$ & 0.758 & & & \\
\hline $\begin{array}{l}\text { Considering the climate of the holiday } \\
\text { destination }\end{array}$ & 0.757 & & & \\
\hline $\begin{array}{l}\text { Well organized everything to be free from } \\
\text { worry }\end{array}$ & 0.587 & & & \\
\hline Well-defined route and maps prior to leaving & 0.579 & & & \\
\hline Factor 5: Group travel & & 1.44 & 5.75 & 0.67 \\
\hline Guided tours & 0.808 & & & \\
\hline Travelling in groups & 0.752 & & & \\
\hline Interacting with other tourists & 0.631 & & & \\
\hline $\begin{array}{l}\text { Visiting places where the people speak the } \\
\text { Korean language (e.g. Korean restaurant, } \\
\text { Korean motel, etc.) }\end{array}$ & 0.524 & & & \\
\hline Factor 6: Indecisive & & 1.35 & 5.41 & 0.67 \\
\hline Difficulty in deciding travel destination & 0.820 & & & \\
\hline $\begin{array}{l}\text { Asking the advice of friends regarding } \\
\text { holiday spots }\end{array}$ & 0.750 & & & \\
\hline Difficulty getting information on travel & 0.689 & & & \\
\hline Factor 7: Variety & & 1.00 & 4.01 & 0.67 \\
\hline Visiting places with a range of shopping & 0.735 & & & \\
\hline Visiting places on the occasion of a festival & 0.710 & & & \\
\hline $\begin{array}{l}\text { Visiting places with a large variety of } \\
\text { activities and sights }\end{array}$ & 0.629 & & & \\
\hline Total variance explained & & & 60.50 & \\
\hline
\end{tabular}


Table 3

Profiling the travel-specific lifestyle segments

\begin{tabular}{lcccc}
\hline & $\begin{array}{c}\text { Culturally safe } \\
\text { travellers }\end{array}$ & $\begin{array}{c}\text { Non-sports } \\
\text { activity } \\
\text { seeking } \\
\text { travellers }\end{array}$ & $\begin{array}{c}\text { Independent } \\
\text { active } \\
\text { travellers }\end{array}$ & $\begin{array}{c}\text { Group } \\
\text { travellers }\end{array}$ \\
\hline Percentage of respondents (\%) & 19.7 & 20.8 & 34.8 & 24.7 \\
\hline Factor 1: Cultural experience & 0.57 & -0.31 & 0.31 & -0.61 \\
Factor 2: Travel interest & 0.40 & 0.00 & 0.16 & -0.60 \\
Factor 3: Sports interest & -0.71 & -0.71 & 0.69 & 0.10 \\
and information seeking & 0.61 & -0.07 & 0.04 & -0.47 \\
Factor 4: Safety and & 0.31 & -0.17 & -0.39 & 0.40 \\
predictability & 0.49 & -1.07 & 0.19 & 0.21 \\
Factor 5: Group travel & -0.39 & 0.51 & 0.31 & -0.54 \\
Factor 6: Indecisive & & & & \\
Factor 7: Variety & & & & \\
\hline
\end{tabular}

The cluster descriptors are based on the factor scores, which were derived from travel-specific lifestyle data and have a mean of zero, and standard deviation of one. 
Table 4

Profiling the differences between Koreans in Australia and Koreans

\begin{tabular}{lcc}
\hline Clusters & Koreans in Australia & Koreans \\
& $\mathrm{n}(\%)$ & $62(22.0)$ \\
\hline Culturally safe travellers & $47(17.2)$ & $44(15.6)$ \\
Non-sports activity seeking travellers & $71(26.1)$ & $93(33.0)$ \\
Independent active travellers & $100(36.8)$ & $83(29.4)$ \\
Group travellers & $54(19.9)$ & $282(100)$ \\
Total & $272(100)$ & \\
\hline
\end{tabular}


Table 5

Comparison of travel experiences and preferences between Koreans in Australia and Koreans

\begin{tabular}{|c|c|c|}
\hline & $\begin{array}{l}\text { Koreans in Australia } \\
\mathrm{n} \text { (\% within group) }\end{array}$ & $\begin{array}{l}\text { Koreans } \\
\mathrm{n} \text { (\% within group) }\end{array}$ \\
\hline \multicolumn{3}{|c|}{ Frequency of international holidays $\left(\chi^{2}=35.07, \mathrm{df}=2, p=<\mathbf{0 . 0 0 1} *\right.$, Cramer's $\left.\mathrm{V}=.25\right)$} \\
\hline Less than once a year & $140(52.0)$ & $214(75.9)$ \\
\hline $1-2$ times a year & $105(39.0)$ & $51(18.1)$ \\
\hline 3 or more times a year & $24(8.9)$ & $17(6.0)$ \\
\hline \multicolumn{3}{|c|}{ Average length of holiday overseas $\left(\chi^{2}=82.34, \mathrm{df}=2, p=<\mathbf{0 . 0 0 1}\right.$, Cramer's $\left.\mathrm{V}=. \mathbf{4 5}\right)$} \\
\hline Less than a week & $75(30.1)$ & $124(74.3)$ \\
\hline $1-2$ weeks & $92(36.9)$ & $32(19.2)$ \\
\hline 3 weeks or more & $82(32.9)$ & $11(6.6)$ \\
\hline \multicolumn{3}{|c|}{ Arrangement of holiday overseas $\left(\chi^{2}=87.71, \mathrm{df}=1, p=<\mathbf{0 . 0 0 1} *\right.$, Phi $\left.=-.44\right)$} \\
\hline Making arrangements through a travel agency & $64(24.9)$ & $139(69.2)$ \\
\hline Making arrangements by myself & $193(75.1)$ & $62(30.8)$ \\
\hline \multicolumn{3}{|c|}{ Frequency of domestic holidays $\left(\chi^{2}=76.43, \mathrm{df}=2, p=<\mathbf{0 . 0 0 1} *\right.$, Cramer's $\left.\mathrm{V}=. \mathbf{3 7}\right)$} \\
\hline Less than once a year & $135(50.0)$ & $49(17.4)$ \\
\hline 1-2 times a year & $74(27.4)$ & $86(30.5)$ \\
\hline 3 or more times a year & $61(22.6)$ & $147(52.1)$ \\
\hline \multicolumn{3}{|c|}{ Average length of domestic holidays $\left(\chi^{2}=86.71, \mathrm{df}=1, p=<\mathbf{0 . 0 0 1} *\right.$, Phi $\left.=-\mathbf{. 4 1}\right)$} \\
\hline 1 - 2 days & $68(26.8)$ & $186(67.6)$ \\
\hline 3 days or more & $186(73.2)$ & $89(32.4)$ \\
\hline \multicolumn{3}{|c|}{ Arrangement of domestic holiday $\left(\chi^{2}=2.30, \mathrm{df}=1, p=0.101\right)$} \\
\hline Making arrangements through a travel agency & $43(16.3)$ & $31(11.4)$ \\
\hline Making arrangements by myself & $220(83.7)$ & $240(88.6)$ \\
\hline \multicolumn{3}{|c|}{ Type of accommodation $\left(\chi^{2}=47.76, \mathrm{df}=3, p=<\mathbf{0 . 0 0 1} *\right.$, Cramer's $\left.\mathrm{V}=\mathbf{. 3 0}\right)$} \\
\hline Hotel & $97(36.1)$ & $38(14.3)$ \\
\hline Motel & $59(21.9)$ & $62(23.3)$ \\
\hline Condominium/Apartment & $64(23.8)$ & $127(47.7)$ \\
\hline The others (camping, backpackers, etc) & $49(18.2)$ & $39(14.7)$ \\
\hline \multicolumn{3}{|c|}{ Travelling companion $\left(\chi^{2}=17.96, \mathrm{df}=2, p=<\mathbf{0 . 0 0 1} *\right.$, Cramer's $\left.\mathrm{V}=\mathbf{. 1 8}\right)$} \\
\hline With family & $181(68.0)$ & $156(56.5)$ \\
\hline With friends & $38(14.3)$ & $81(29.3)$ \\
\hline The others (alone, with partner, etc.) & $47(17.7)$ & $39(14.1)$ \\
\hline
\end{tabular}

Significant level at $p<0.001 *$ 
Table 6

Summary of significant differences between the two groups

\begin{tabular}{lccc} 
& $\begin{array}{c}\text { Koreans in } \\
\text { Australia }\end{array}$ & Koreans in Korea & Effect size $^{\text {a }}$ \\
\hline Frequency of overseas holidays greater & + & - & .06 \\
Length of overseas trip longer & + & - & .20 \\
Arrange overseas trip: self & + & - & .19 \\
Arrange overseas trip: agency & - & + & .19 \\
Frequency of domestic holidays greater & - & + & .14 \\
Length of domestic holiday longer & + & - & .17 \\
Accommodation style: hotels & + & - & .09 \\
Accommodation style: apartments & - & - & .03 \\
Travel with family & + & + & .03 \\
Travel with friends & - & - & .03 \\
Cluster non-sports activity seeker & + & + & .03 \\
Cluster group traveller & - & + & \\
\hline
\end{tabular}

a. Effect size is based on Cramer's V or Phi, squared, for the chi-square test 
Table 7

Profiling the travel-specific lifestyle segments among Koreans in Australia based on demographics and travel experiences

\begin{tabular}{|c|c|c|c|c|}
\hline & $\begin{array}{c}\text { Culturally } \\
\text { safe travellers }\end{array}$ & $\begin{array}{l}\text { Non-sports } \\
\text { activity } \\
\text { seeking } \\
\text { travellers } \\
\end{array}$ & $\begin{array}{l}\text { Independent } \\
\text { active } \\
\text { travellers }\end{array}$ & $\begin{array}{l}\text { Group } \\
\text { travellers }\end{array}$ \\
\hline & \multicolumn{4}{|c|}{$\mathrm{n}(\%$ within cluster $)$} \\
\hline \multicolumn{5}{|c|}{ Gender $\left(\chi^{2}=14.62, \mathrm{df}=3, p=\mathbf{0 . 0 0 2} *\right.$ Cramer's $\left.\mathrm{V}=. \mathbf{2 3}\right)$} \\
\hline Male $\quad x$ m & $11(23.4)$ & $22(31.0)$ & $48(48.0)$ & $29(53.7)$ \\
\hline Female & $36(76.6)$ & $49(69.0)$ & $52(52.0)$ & $25(46.3)$ \\
\hline \multicolumn{5}{|l|}{$\operatorname{Age}\left(\chi^{2}=12.46, \mathrm{df}=9, p=0.189\right)$} \\
\hline $20-29$ years & $5(10.6)$ & $21(29.6)$ & $20(20.0)$ & $12(22.2)$ \\
\hline 30-39 years & $17(36.2)$ & $26(36.6)$ & $33(33.0)$ & $14(25.9)$ \\
\hline $40-49$ years & $17(36.2)$ & $16(22.5)$ & $39(39.0)$ & $21(38.9)$ \\
\hline 50 years and over & $8(17.0)$ & $8(11.3)$ & $8(8.0)$ & $7(13.0)$ \\
\hline \multicolumn{5}{|l|}{ Marital Status $\left(\chi^{2}=5.70, \mathrm{df}=3, p=0.127\right)$} \\
\hline Never married & $9(20.0)$ & $20(29.0)$ & $14(14.0)$ & $11(20.8)$ \\
\hline Married/De facto & $36(80.0)$ & $49(71.0)$ & $86(86.0)$ & $42(79.2)$ \\
\hline \multicolumn{5}{|l|}{ Education $\left(\chi^{2}=2.93, \mathrm{df}=6, p=0.817\right)$} \\
\hline Postgraduate (Masters or $\mathrm{PhD}$ ) & $6(12.8)$ & $10(14.5)$ & $18(18.2)$ & $5(9.3)$ \\
\hline Bachelor Degree & $34(72.3)$ & $46(68.1)$ & $63(63.6)$ & $38(70.4)$ \\
\hline Senior High School or less & $7(14.9)$ & $12(17.4)$ & $18(18.2)$ & $11(20.4)$ \\
\hline \multicolumn{5}{|l|}{ Income $\left(\chi^{2}=2.19, \mathrm{df}=6, p=0.901\right)$} \\
\hline Less than $A \$ 40,000$ per annum & $27(60.0)$ & $29(49.2)$ & $48(53.9)$ & $24(52.2)$ \\
\hline A $\$ 40,000$ - A $\$ 69,999$ per annum & $10(22.2)$ & $19(32.2)$ & $28(31.5)$ & $15(32.6)$ \\
\hline A $\$ 70,000$ or more per annum & $8(17.8)$ & $11(18.6)$ & $13(14.6)$ & $7(15.2)$ \\
\hline \multicolumn{5}{|c|}{ Frequency of international holidays $\left(\chi^{2}=8.88, \mathrm{df}=3, p=\mathbf{0 . 0 3 1 * *}\right.$, Cramer's $\left.\mathrm{V}=\mathbf{. 1 8}\right)$} \\
\hline Less than once a year & $25(53.2)$ & $38(54.3)$ & $41(41.8)$ & $36(66.7)$ \\
\hline Once a year or more & $22(46.8)$ & $32(45.7)$ & $57(58.2)$ & $18(33.3)$ \\
\hline \multicolumn{5}{|c|}{ Average length of holiday overseas $\left(\chi^{2}=12.67, \mathrm{df}=3, p=\mathbf{0 . 0 0 5}\right.$, Cramer's $\left.\mathrm{V}=. \mathbf{2 3}\right)$} \\
\hline Less than a week & $9(19.6)$ & $13(20.3)$ & $31(33.3)$ & $22(47.8)$ \\
\hline 1 week or more & $37(80.4)$ & $51(79.7)$ & $62(66.7)$ & $24(52.2)$ \\
\hline \multicolumn{5}{|c|}{ Arrangement of holiday overseas $\left(\chi^{2}=12.69, \mathrm{df}=3, p=\mathbf{0 . 0 0 5} *\right.$, Cramer's V $\left.=.22\right)$} \\
\hline Making arrangements through a travel agency & $18(39.1)$ & $9(13.8)$ & $20(20.6)$ & $17(34.7)$ \\
\hline Making arrangements by myself & $28(60.9)$ & $56(86.2)$ & $77(79.4)$ & $32(65.3)$ \\
\hline \multicolumn{5}{|c|}{ Frequency of domestic holidays $\left(\chi^{2}=12.12, \mathrm{df}=6, p=0.059\right)$} \\
\hline Less than once a year & $20(43.5)$ & $36(50.7)$ & $43(43.4)$ & $36(66.7)$ \\
\hline 1-2 times a year & $13(28.3)$ & $24(33.8)$ & $28(28.3)$ & $9(16.7)$ \\
\hline 3 or more times a year & $13(28.3)$ & $11(15.5)$ & $28(28.3)$ & $9(16.7)$ \\
\hline \multicolumn{5}{|c|}{ Average length of domestic holidays $\left(\chi^{2}=4.70, \mathrm{df}=3, p=0.195\right)$} \\
\hline 1 - 2 days & $9(19.6)$ & $24(36.4)$ & $24(25.3)$ & $11(23.4)$ \\
\hline 3 days or more & $37(80.4)$ & $42(63.6)$ & $71(74.7)$ & $36(76.6)$ \\
\hline \multicolumn{5}{|c|}{ Arrangement of domestic holiday $\left(\chi^{2}=7.21, \mathrm{df}=3, p=0.065\right)$} \\
\hline Making arrangements through a travel agency & $7(14.9)$ & $6(9.1)$ & $16(16.2)$ & $14(27.5)$ \\
\hline Making arrangements by myself & $40(85.1)$ & $60(90.9)$ & $83(83.8)$ & $37(72.5)$ \\
\hline \multicolumn{5}{|c|}{ Type of accommodation $\left(\chi^{2}=14.49, \mathrm{df}=9, p=0.106\right)$} \\
\hline Hotel & $17(36.2)$ & $31(44.3)$ & $28(28.3)$ & $21(39.6)$ \\
\hline Motel & $12(25.5)$ & $12(17.1)$ & $21(21.2)$ & $14(26.4)$ \\
\hline Condominium/Apartment & $9(19.1)$ & $10(14.3)$ & $32(32.3)$ & $13(24.5)$ \\
\hline The others (camping, backpackers, etc) & $9(19.1)$ & $17(24.3)$ & $18(18.2)$ & $5(9.4)$ \\
\hline
\end{tabular}




\begin{tabular}{lllll}
\hline Travelling companion $\left(\chi^{2}=8.06, \mathrm{df}=6, p=0.234\right)$ & & & \\
With family & $35(74.5)$ & $45(65.2)$ & $68(69.4)$ & $33(63.5)$ \\
With friends & $7(14.9)$ & $12(17.4)$ & $8(8.2)$ & $11(21.2)$ \\
The others (alone, with partner, etc.) & $5(10.6)$ & $12(17.4)$ & $22(22.4)$ & $8(15.4)$ \\
\hline
\end{tabular}

Significant level at $\mathrm{p}<0.01^{*}, 0.05^{* *}$ 
Table 8

Profiling the travel-specific lifestyle segments among Koreans based on demographics and travel experiences

\begin{tabular}{|c|c|c|c|c|}
\hline & $\begin{array}{c}\text { Culturally } \\
\text { safe travellers }\end{array}$ & $\begin{array}{l}\text { Non-sports } \\
\text { activity } \\
\text { seeking } \\
\text { travellers }\end{array}$ & $\begin{array}{l}\text { Independent } \\
\text { active } \\
\text { travellers }\end{array}$ & $\begin{array}{c}\text { Group } \\
\text { travellers }\end{array}$ \\
\hline & \multicolumn{4}{|c|}{$\mathrm{n}(\%$ within cluster $)$} \\
\hline \multicolumn{5}{|l|}{ Gender $\left(\chi^{2}=4.35, \mathrm{df}=3, p=0.227\right)$} \\
\hline Male & $19(30.6)$ & $18(40.9)$ & $34(36.6)$ & $39(47.0)$ \\
\hline Female & $43(69.4)$ & $26(59.1)$ & $59(63.4)$ & $44(53.0)$ \\
\hline \multicolumn{5}{|l|}{ Age $\left(\chi^{2}=15.85, \mathrm{df}=9, p=0.070\right)$} \\
\hline $20-29$ years & $9(14.5)$ & $9(20.5)$ & $30(32.3)$ & $13(15.7)$ \\
\hline $30-39$ years & $19(30.6)$ & $15(34.1)$ & $30(32.3)$ & $29(34.9)$ \\
\hline $40-49$ years & $23(37.1)$ & $10(22.7)$ & $26(28.0)$ & $26(31.3)$ \\
\hline 50 years and over & $11(17.7)$ & $10(22.7)$ & $7(7.5)$ & $15(18.1)$ \\
\hline \multicolumn{5}{|l|}{ Marital Status $\left(\chi^{2}=6.08, \mathrm{df}=3, p=0.108\right)$} \\
\hline Never married & $14(24.1)$ & $11(26.2)$ & $34(37.4)$ & $18(21.7)$ \\
\hline Married/De facto & $44(75.9)$ & $31(73.8)$ & $57(62.6)$ & $65(78.3)$ \\
\hline \multicolumn{5}{|l|}{ Education $\left(\chi^{2}=8.82, \mathrm{df}=6, p=0.184\right)$} \\
\hline Postgraduate (Masters or PhD) & $6(9.7)$ & $1(2.3)$ & $13(14.0)$ & $7(8.4)$ \\
\hline Bachelor Degree & $31(50.0)$ & $19(44.2)$ & $42(45.2)$ & $48(57.8)$ \\
\hline Senior High School or less & $25(40.3)$ & $23(53.5)$ & $38(40.9)$ & $28(33.7)$ \\
\hline \multicolumn{5}{|l|}{ Income $\left(\chi^{2}=2.24, \mathrm{df}=6, p=0.896\right)$} \\
\hline Less than $2,000,000$ won per month & $27(45.8)$ & $24(57.1)$ & $42(47.7)$ & $40(50.0)$ \\
\hline $2,000,001-4,000,000$ won per month & $21(35.6)$ & $14(33.3)$ & $31(35.2)$ & $28(35.0)$ \\
\hline $4,000,001$ won or more per month & $11(18.6)$ & $4(9.5)$ & $15(17.0)$ & $12(15.0)$ \\
\hline \multicolumn{5}{|c|}{ Frequency of international holidays $\left(\chi^{2}=1.61, \mathrm{df}=3, p=0.658\right)$} \\
\hline Less than once a year & $50(80.6)$ & $33(75.0)$ & $67(72.0)$ & $64(77.1)$ \\
\hline Once a year or more & $12(19.4)$ & $11(25.0)$ & $26(28.0)$ & $19(22.9)$ \\
\hline \multicolumn{5}{|c|}{ Average length of holiday overseas $\left(\chi^{2}=2.43, \mathrm{df}=3, p=0.488\right)$} \\
\hline Less than a week & $31(81.6)$ & $19(76.0)$ & $40(67.8)$ & $34(75.6)$ \\
\hline 1 week or more & $7(18.4)$ & $6(24.0)$ & $19(32.2)$ & $11(24.4)$ \\
\hline \multicolumn{5}{|c|}{ Arrangement of holiday overseas $\left(\chi^{2}=4.96, \mathrm{df}=3, p=0.175\right)$} \\
\hline Making arrangements through a travel agency & $38(80.9)$ & $20(60.6)$ & $43(64.2)$ & $38(70.4)$ \\
\hline Making arrangements by myself & $9(19.1)$ & $13(39.4)$ & $24(35.8)$ & $16(29.6)$ \\
\hline \multicolumn{5}{|c|}{ Frequency of domestic holidays $\left(\chi^{2}=22.96, \mathrm{df}=6, p=\mathbf{0 . 0 0 1} *\right.$ Cramer's $\left.\mathrm{V}=. \mathbf{2 0}\right)$} \\
\hline Less than once a year & $7(11.3)$ & $11(25.0)$ & $8(8.6)$ & $23(27.7)$ \\
\hline $1-2$ times a year & $15(24.2)$ & $13(29.5)$ & $27(29.0)$ & $31(37.3)$ \\
\hline 3 or more times a year & $40(64.5)$ & $20(45.5)$ & $58(62.4)$ & $29(34.9)$ \\
\hline \multicolumn{5}{|c|}{ Average length of domestic holidays $\left(\chi^{2}=3.58, \mathrm{df}=3, p=0.311\right)$} \\
\hline 1 - 2 days & $43(70.5)$ & $30(71.4)$ & $56(60.2)$ & $57(72.2)$ \\
\hline 3 days or more & $18(29.5)$ & $12(28.6)$ & $37(39.8)$ & $22(27.8)$ \\
\hline \multicolumn{5}{|c|}{ Arrangement of domestic holiday $\left(\chi^{2}=4.77, \mathrm{df}=3, p=0.190\right)$} \\
\hline Making arrangements through a travel agency & $8(13.3)$ & $4(9.3)$ & $6(6.6)$ & $13(16.9)$ \\
\hline Making arrangements by myself & $52(86.7)$ & $39(90.7)$ & $85(93.4)$ & $64(83.1)$ \\
\hline \multicolumn{5}{|c|}{ Type of accommodation $\left(\chi^{2}=9.94, \mathrm{df}=9, p=0.356\right)$} \\
\hline Hotel & $13(22.0)$ & $5(12.5)$ & $13(14.3)$ & $7(9.2)$ \\
\hline Motel & $16(27.1)$ & $11(27.5)$ & $20(22.0)$ & $15(19.7)$ \\
\hline Condominium/Apartment & $23(39.0)$ & $18(45.0)$ & $48(52.7)$ & $38(50.0)$ \\
\hline The others (camping, backpackers, etc) & $7(11.9)$ & $6(15.0)$ & $10(11.0)$ & $16(21.1)$ \\
\hline
\end{tabular}


Travelling companion $\left(\chi^{2}=7.63, \mathrm{df}=6, p=0.267\right)$

With family

$36(59.0)$

$20(48.8)$

$55(59.1)$

$45(55.6)$

With friends

$13(21.3)$

$12(29.3)$

$28(30.1)$

$28(34.6)$

The others (alone, with partner, etc.)

$12(19.7)$

$9(22.0)$

$10(10.8)$

$8(9.9)$

Significant level at $\mathrm{p}<0.01 *$ 